\title{
Treatment of Mining and Thermoelectric Waste Through the Geopolymerization Process
}

\author{
Morales-Aranibar Carlos ${ }^{1 *}$, Linares Nataniel $^{2}$, Soto Tolomeo $^{3}$, and Morales-Aranibar Luis ${ }^{4}$ \\ ${ }^{1}$ Metallurgist Engineer from the Jorge Basadre Grohmann National University \\ ${ }^{2}$ Principal professor of the Professional School of Metallurgical and Materials Engineering of the Jorge Basadre Grohmann National \\ University \\ ${ }^{3}$ Rector of the Jorge Basadre Grohmann National University. \\ ${ }^{4}$ Director of the Office of Innovation, Technology Transfer and Intellectual Property at the National Intercultural University of \\ Quillabamba
}

\begin{abstract}
Currently, energy and extraction activities generate large amounts of highly polluting waste, so there is a need for sustainable and environmentally friendly technologies. The aim of the study is to treat mining tailings and fly ash through the process of geopolymerization. The samples studied were obtained from the Toquepala mine, Tacna and from the ENGIE-Moquegua hydroelectric plant (Peru). The methodology was based on two stages, the first characterization of Fly Ash (FA) and mine tailings (MT) by EDX chemical characterization, SEM morphology, the second was prepared mixtures of MT and FA in $10 \mathrm{M}$ alkaline solution, cured in 35 days at room temperature and the characterization of the geopolymer by organoleptic analysis, SEM and TCLP. The first stage shows high aluminosilicate content $20.44 \%$ $\mathrm{Al}_{2} \mathrm{O}_{3}$ and $53.39 \% \mathrm{SiO}_{2}$ for (MT); $22.11 \% \mathrm{Al}_{2} \mathrm{O}_{3}$ and $51.76 \% \mathrm{SiO}_{2}$ for (FA), presents metal and pyrite content. In the second stage, the samples show health and environmental harmlessness, with the formation of tetragonal structures typical of the geopolymer, the samples show a significant reduction of $\mathrm{Sr}, \mathrm{Ca}, \mathrm{Fe}$, $\mathrm{Pb}, \mathrm{Ba}, \mathrm{Be}$, and $\mathrm{Cu}$, demonstrating the effectiveness of treatment by means of geopolymerization opening a new field for the environmental passive treatment.
\end{abstract}

\section{Introduction}

Pollution from industrial mining and thermoelectric waste, which causes severe environmental alterations worldwide, presents great difficulty in its treatment because large amounts of mass are produced daily. This has motivated different researchers to develop technologies for the management and processing of mining and thermoelectric liabilities [1].

At a global level, the growing boom in technology has generated an important need for raw materials such as metal elements for the shaping of these technologies, leading to a mining boom, which has become a major socio-environmental problem for the population as the environment has been altered and sustainable methods are being sought to mitigate their impact [2]. On the other hand, the thermoelectric industries are of great concern, given that the transition to new green technologies will take a long time for Third World countries such as Peru [3], so it is of vital importance to develop new affordable and low-cost technologies for the treatment of mining and thermoelectric waste. Industrial processes such as copper mining, where huge quantities of tailings are discharged into tailings ponds [4] and coal burning for electricity generation, generate large quantities of coal, leaving fly ash as a by-product [5], use techniques that move enormous quantities of materials to extract valuable metals and produce electricity, however, these contaminants possess metallic elements such as $\mathrm{Cu}, \mathrm{B}, \mathrm{Be}, \mathrm{Co}$, Mo, present in the tailings and fly ashes, these are harmful to soil and water as they are potentially reactive by surrounding water bodies which could generate acidic water [6] [7],

These wastes are environmental liabilities that need immediate recourse, not only to remediation or mitigation but also to seek new technologies that allow us to restore and give added value to these pollutants [8], where society, environment and economy are in balance, being these industries the ones that move the country economically [9].

Globally, these mining and thermoelectric wastes have an inherent composition of aluminosilicates present in mining tailings and fly ashes that are industrial passives that need to be recovered and treated [10] [11]. Encapsulation is a process involving tailings and ashes that, when agglomerated under alkaline conditions, achieve appropriate properties and chemical stability, forming geopolymers that are capable of stabilising these contaminants, in addition to giving them other sustainable uses [12]. Therefore, it is proposed to treat mining tailings and fly ash by means of the geopolymerization process.

\section{Materials and methods}

* Corresponding author: cgmoralesa@unjbg.edu.pe 


\subsection{Sample selection}

The samples were taken in situ, the fly ash samples (FA) were provided by the ENGIE thermal power plant in the city of Ilo, and the mining tailings from Quebrada Honda of the Southern Peru Copper Corporation mining company in Tacna. The samples were studied at the mineralurgy laboratory of the Universidad Nacional Jorge Basadre Grohmann in Tacna

\section{Methodology}

The methodology for carrying out this research was divided into two stages, the first in which the MT and FA are physically, morphologically and chemically characterized; and a second stage where the physical, morphological and chemical properties of the geopolymer formed by MT and FA are characterized.

\subsection{First stage: Primary characterization of the raw materials.}

(a) Physical characterization: Tailings and fly ash samples were characterized by sieve analysis and specific gravity by the pycnometer method [13] [29].

(b) Morphological characterization: The samples were analyzed by scanning electron microscopy instrumental analysis [14] [30].

(c) Chemical characterization: The elements present were determined by instrumental analysis EDX Energy Dispersive X-Ray Spectroscopy [15] [31].

\subsection{Second stage: Formulation of the geopolymer and characterization.}

Different mixtures composed of fly ash and mining tailings were developed, these were activated and agglomerated by means of a sodium hydroxide solution with a liquid solid ratio of 5 to 1 with a molarity of 10 $\mathrm{M}$, these were cured in the open air for 35 days for their characterization [16] [32]

(a) Physical characterization: The geopolymer briquettes formed from the industrial wastes passed organoleptic tests.

(b) Morphological Characterization: The geopolymer samples were analysed by scanning electron microscopy [17] [33].

(c) Chemical Characterization: For which the TCLP (Toxicity characteristic leaching procedure) instrumental analysis was performed for the best geopolymer. [18] [19].

\section{Results}

\subsection{First stage: primary characterization of raw materials.}

a) Physical Characterization: Particle size analysis, for the tailings shows a fine particle size below the $106 \mu \mathrm{m}$ opening, while for the fly ashes it shows a fine particle size below $60 \mu \mathrm{m}$ denoted in Figure 1, these ones have a specific gravity of 2.86 for the tailings and 2.21 for the fly ashes.

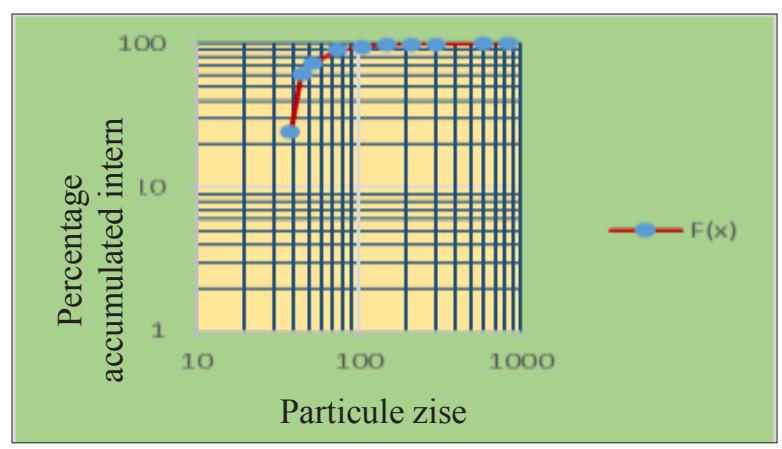

Fig. 1. Particle size distribution for fly ash.

b) Morphological Characterization: A heterogeneous particulate material with the presence of metallic content on the surface of the samples is observed at 100 magnification resolution the presence of pyrites and iron oxides, shown in figure 2 and 3.

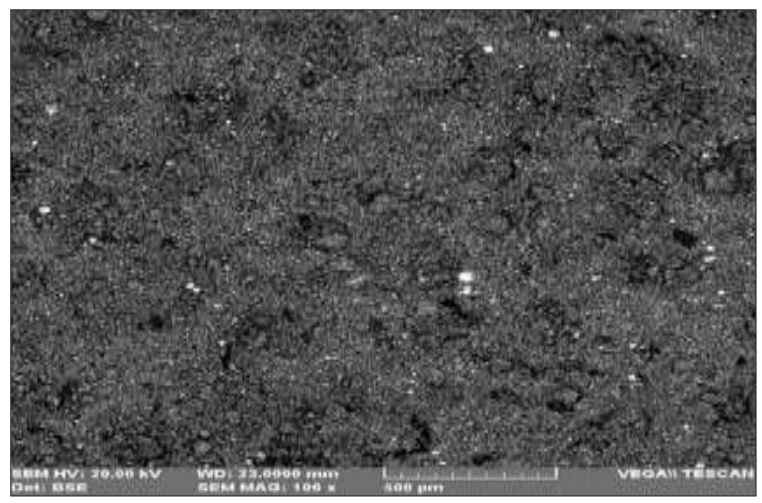

Fig. 2. Microphotography of tailings at 100x resolution

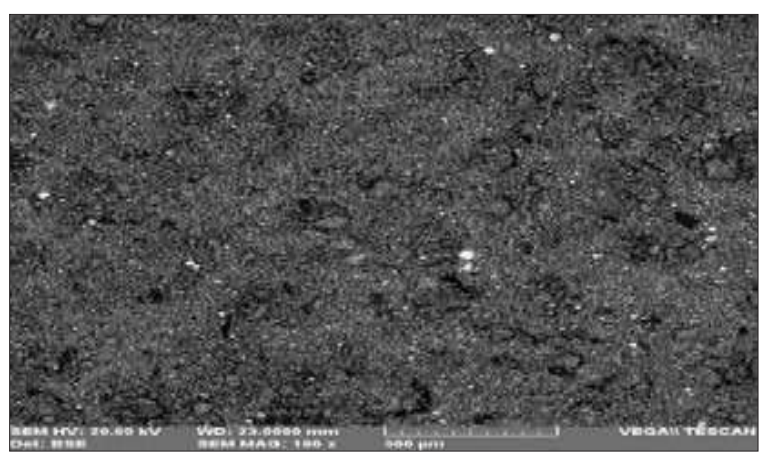

Fig. 3. Microphotography of fly ash at 100x resolution

c) Chemical characterization: Quantitative chemical compositional analysis for tailings and fly ashes, showed a high percentage of elements that are important for geopolymer formation, such as silicates and oxides present in tailings and fly ashes and they are important for geopolymerization.

When these come into contact with the $\mathrm{NaOH}$ activating solution, they form the geopolymer. The 
presence of typical elements such as Sulphur oxides and iron oxides of the composition of tailings and fly ashes, which are highly contaminating due to their particle size and chemical reactivity, was also evident, as shown in Table 1 and Table 2.

Table 1. EDAX chemical composition analysis results for tailings

\begin{tabular}{|c|c|}
\hline Formula & $\begin{array}{c}\text { Composition \% } \\
\text { Relave }\end{array}$ \\
\hline $\mathrm{MgO}$ & 2,05 \\
\hline $\mathrm{Al}_{2} \mathrm{O}_{3}$ & 20,44 \\
\hline $\mathrm{SiO}_{2}$ & 53,39 \\
\hline $\mathrm{SO}_{3}$ & 8,81 \\
\hline $\mathrm{K}_{2} \mathrm{O}$ & 6,97 \\
\hline $\mathrm{CaO}$ & 2,71 \\
\hline $\mathrm{FeO}$ & 5,63 \\
\hline
\end{tabular}

Table 2. EDAX chemical composition analysis results for fly ash.

\begin{tabular}{|c|c|}
\hline Formula & $\begin{array}{c}\text { Composition \%. } \\
\text { Fly ash }\end{array}$ \\
\hline $\mathrm{Na}_{2} \mathrm{O}$ & 5,25 \\
\hline $\mathrm{MgO}$ & 1,53 \\
\hline $\mathrm{Al}_{2} \mathrm{O}_{3}$ & 22,11 \\
\hline $\mathrm{SiO}_{2}$ & 51,76 \\
\hline $\mathrm{SO}_{3}$ & 2,58 \\
\hline $\mathrm{K}_{2} \mathrm{O}$ & 2,67 \\
\hline $\mathrm{CaO}$ & 4,63 \\
\hline $\mathrm{FeO}$ & 9,47 \\
\hline
\end{tabular}

\subsection{Second stage: formulation of the geopolymer and characterization.}

a) Physical characterization: The formed briquettes showed particular properties according to their nature and mixture, it presents an average density of $2,12 \mathrm{~g} / \mathrm{cm} 3$, a significant reduction in the smell was evidenced, the briquettes could be easily manipulated without raising dust in the environment and health, the colour is maintained between lead shades evidenced in table 3 .

b) Morphological Characterization: The geopolymer shows tetragonal structures typical of geopolymers, which shows the encapsulation and formation of the geopolymer, which provides high mechanical resistance and the insertion of the pollutants. This tetragonal structure allows the reduction of pollutants that are harmful to the environment, which can be seen in figure 4 .

Table 3. Characterization of the organoleptic properties of the components and the geopolymer.

\begin{tabular}{|l|l|l|l|}
\hline Type & Colour & Smell & Touch \\
\hline Pure Tailings & $\begin{array}{l}\text { They are } \\
\text { in a } \\
\text { leaden } \\
\text { tone. }\end{array}$ & $\begin{array}{l}\text { It has a } \\
\text { mild } \\
\text { sulphurous } \\
\text { mineral } \\
\text { odour and a } \\
\text { rotten egg } \\
\text { smell. }\end{array}$ & $\begin{array}{l}\text { It is presented } \\
\text { as a powder } \\
\text { with a rough } \\
\text { and fragile } \\
\text { surface. }\end{array}$ \\
\hline Pure Fly Ash & $\begin{array}{l}\text { They } \\
\text { have a } \\
\text { dark lead } \\
\text { colour. }\end{array}$ & $\begin{array}{l}\text { Presents a } \\
\text { mild smell } \\
\text { of oxidised } \\
\text { minerals }\end{array}$ & $\begin{array}{l}\text { It is presented } \\
\text { as a powder } \\
\text { with a smooth } \\
\text { and fragile } \\
\text { surface. }\end{array}$ \\
\hline Geopolymer & $\begin{array}{l}\text { They } \\
\text { vary with } \\
\text { the } \\
\text { presence } \\
\text { of light } \\
\text { to darker } \\
\text { shades of } \\
\text { lead fly } \\
\text { ash }\end{array}$ & $\begin{array}{l}\text { Odourless } \\
\text { hmooth and } \\
\text { hard surface, } \\
\text { in some cases } \\
\text { the presence } \\
\text { of silicon } \\
\text { crystals } \\
\text { similar to the } \\
\text { common } \\
\text { efflorescence } \\
\text { is observed }\end{array}$ \\
\hline
\end{tabular}

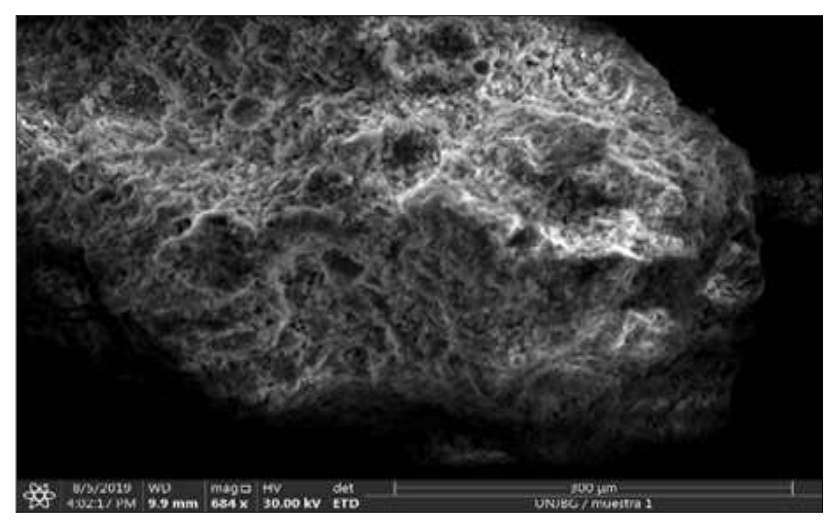

Fig 4. Micrograph of the geopolymer at 300 magnification.

c) Chemical characterization:

Results of the TCLP (Toxicity characteristic leaching procedure)

A large reduction in the levels of pollutants is observed in comparison with sample 1 pure binder mixture and the geopolymer formed in sample 2, a significant decrease in pollutants such as $\mathrm{Pb}, \mathrm{Ba}$, $\mathrm{Be}$, and $\mathrm{Cu}$, which are harmful to the environment, it is shown in (Table 4). 
Table 4. TCLP Test Analysis

\begin{tabular}{|c|c|c|c|c|c|}
\hline Type mg/L & Sample 1 & Sample 2 & Type mg/L & Sample 1 & Sample 2 \\
\hline $\mathrm{Ag}(\mathrm{t})$ & $<0.002$ & $<0.002$ & $\mathrm{Li}(\mathrm{t})$ & $<0.004$ & 0.639 \\
\hline $\mathrm{Al}(\mathrm{t})$ & 4.17 & 0.91 & $\mathrm{Mg}(\mathrm{t})$ & 16.21 & 9.79 \\
\hline $\mathrm{Zn}(\mathrm{t})$ & 0.279 & 0.016 & $\mathrm{Mn}(\mathrm{t})$ & 1.277 & 0.012 \\
\hline $\mathrm{B}(\mathrm{t})$ & 3.122 & 2.243 & $\mathrm{Mo}(\mathrm{t})$ & $<0.004$ & 0.483 \\
\hline $\mathrm{Ba}(\mathrm{t})$ & 0.307 & 0.188 & $\mathrm{Na}(\mathrm{t})$ & 2030.05 & 2618.02 \\
\hline $\mathrm{Be}(\mathrm{t})$ & 0.0066 & $<0.0003$ & $\mathrm{Ni}(\mathrm{t})$ & $<0.002$ & $<0.002$ \\
\hline $\mathrm{Bi}(\mathrm{t})$ & $<0.02$ & $<0.02$ & $\mathrm{P}(\mathrm{t})$ & $<0.06$ & 2.08 \\
\hline $\mathrm{Ca}(\mathrm{t})$ & 493.42 & 228.77 & $\mathrm{~Pb}(\mathrm{t})$ & 0.2 & $<0.01$ \\
\hline $\mathrm{Cd}(\mathrm{t})$ & $<0.001$ & $<0.001$ & $\mathrm{Sb}(\mathrm{t})$ & $<0.008$ & $<0.008$ \\
\hline $\mathrm{Ce}(\mathrm{t})$ & $<0.02$ & $<0.02$ & $\mathrm{Se}(\mathrm{t})$ & $<0.02$ & 1.76 \\
\hline $\mathrm{Co}(\mathrm{t})$ & $<0.002$ & $<0.002$ & $\mathrm{Sn}(\mathrm{t})$ & $<0.007$ & $<0.007$ \\
\hline $\mathrm{Cr}(\mathrm{t})$ & $<0.004$ & $<0.004$ & $\mathrm{Sr}(\mathrm{t})$ & 4.3157 & 2.3054 \\
\hline $\mathrm{Cu}(\mathrm{t})$ & 0.469 & 0.005 & $\mathrm{Ti}(\mathrm{t})$ & 0.05 & 0.03 \\
\hline $\mathrm{Fe}(\mathrm{t})$ & 1.12 & 0.33 & $\mathrm{~V}(\mathrm{t})$ & 0.045 & 0.713 \\
\hline $\mathrm{K}(\mathrm{t})$ & 9.89 & 68.5 & & & \\
\hline
\end{tabular}

\section{Discussion}

The particle size of the samples that were studied, reveals a fine size; for mine tailings and fly ash this facilitates the mixing of the components and the geopolymerization reaction, due to the larger surface area of contact of the fine particles with the activating solution. The results are similar to [20] and [15]. The specific gravity for tailings and fly ashes shows that they are light materials, which is reflected in their density facilitating the transport of these encapsulated contaminants for better disposal.

The morphological characterization of the raw materials shows the presence of metallic elements on their surface, such as pyrites and other oxides, which are harmful to the environment and health [7], as well as the presence of environmental humidity typical of the Peruvian coast for Ilo and Tacna, which could generate acidic water, as demonstrated by [21], and contaminate underground tributaries if they are not treated appropriately. This demonstrates the importance of encapsulating industrial waste such as tailings and fly ashes in a chemical mesh such as a geopolymer, as explained by [22].

Due to the industrial origin of the samples, such as the Ilo thermal power plant and the tailings channels of Quebrada Honda, they show a high quantity of important elements for the geopolymerization, such as the aluminosilicates evidenced in the instrumental analyses EDAX with percentages of 20,44\% $\mathrm{Al}_{2} \mathrm{O}_{3}$ and $53.39 \% \mathrm{SiO}_{2}$ for mine tailings and $22.11 \% \mathrm{Al}_{2} \mathrm{O}_{3}$ $51.76 \% \mathrm{SiO}_{2}$ for fly ash, these elements present in mining and thermoelectric waste demonstrate the formation of the geopolymer that was found by [19] and [12].

The activating solution in this case Sodium Hydroxide was very critical and it was demonstrated that the molarity was $10 \mathrm{M}$ for the formation of the geopolymer, with important physical and chemical properties such as high hardness, high mechanical resistance and the formation of tetragonal structures of the geopolymer in which the contaminating elements are inserted for the encapsulation of hazardous waste which in a similar way are demonstrated by [23] and [24] The solid-liquid relationship shows the good workability of the mixture and its low water consumption for the formation of geopolymer briquettes, as well as the evidence of [25], which is a very important property for saving water consumption in desert areas such as the southern coast of Peru, since this is an environmentally sustainable material.

The organoleptic characterization for untreated fly ash and mine tailings in its pure state presents invasive properties to the environment such as bad smell due to the sulphides present and easy spreading in the environment due to the particle size and the form of dust in which it is presented with a fragile surface, which becomes very vulnerable to environmental climate conditions, as shown by [7], [8], this compared to the geopolymer which has a hard surface and greater resistance shows an ecological and environmental alternative to mitigate the impact of these industrial wastes due to the low cost and easy access to this technology.

The morphological characterization for the formed geopolymer shows tetragonal structures. This mesh is responsible for the special physical-chemical properties of the geopolymer, such as its structural resistance, low specific gravity and low chemical reactivity in the environment due to the encapsulation of the contaminating elements in its tetragonal network as evidenced by [26].

The TCLP analysis demonstrates a significant reduction in the levels of the contaminants $\mathrm{Mr}$. $\mathrm{Ca}, \mathrm{Fe}$, $\mathrm{Pb}, \mathrm{Ba}, \mathrm{Be}$, and $\mathrm{Cu}$ present in the raw materials after treatment by geopolymerization, demonstrates the chemical encapsulation of the contaminants, as well as the evidence of Cristelo et al. Elements such as Mo, $\mathrm{Na}, \mathrm{Ni}, \mathrm{P}, \mathrm{K}, \mathrm{Li}$, Se and $\mathrm{V}$, present difficulty to fix this 
kind of ions in the geopolymer matrix due to their high solubility in alkaline environments. This increases their presence in the formed geopolymer, as [27] show in their results, so these elements are scattered in the geopolymer matrix as [28], this predominant mechanism depends on the level of solubility of the heavy metal ions, i.e. the highly soluble elements are more spread throughout the matrix, while the less soluble elements form larger volume nuclei that are then involved by the gel matrix, which makes this geopolymer present a chemical and physical encapsulation for elements such as $\mathrm{Sr}, \mathrm{Ca}, \mathrm{Fe}, \mathrm{Pb}, \mathrm{Ba}$, $\mathrm{Be}$, and $\mathrm{Cu}$ and a physical encapsulation for the other elements $\mathrm{Mo}, \mathrm{Na}, \mathrm{Ni}, \mathrm{P}, \mathrm{K}, \mathrm{Li}$, Se and $\mathrm{V}$, taking into account that the geopolymer formed is an aggregate with great mechanical properties, This marks an absolute difference between other treatments due to the properties obtained in this research work, which was treated under natural environmental conditions in the Tacna Peru region, which shows that it is possible to reduce the contaminating elements without the need to calcine the mixture of raw materials, however the curing time is 35 days to achieve optimal properties in the geopolymer formed, it is recommended to carry out more studies related to the encapsulation of heavy contaminating elements, in addition to studies of future applications of these materials for use in structures or roads.

\section{Conclusion}

The physical and chemical characteristics of mining tailings and fly ashes are ideal for the geopolymerization process at room temperature in alkaline solution, these untreated wastes represent a danger to the environment due to their physical and chemical characteristics such as their volatility and reactivity in the atmosphere, the geopolymer formed has optimum organoleptic properties for final disposal, it shows reduction of odour, fixes the contaminating particles in a tetragonal structure typical of the geopolymer and improves its mechanical properties, showing a significant reduction of the contaminating elements, such as $\mathrm{Sr}, \mathrm{Ca}, \mathrm{Fe}, \mathrm{Pb}, \mathrm{Ba}, \mathrm{Be}$, and $\mathrm{Cu}$ among others, which demonstrates the effectiveness of encapsulation of the contaminating residues, being innocuous with the environment, being able to consider its use for future applications in the treatment of mining and thermoelectric soils.

\section{Aknowledgement}

To the thesis "Immobilization of copper flotation tailings in Tacna through the use of geopolymers" financed with funds from the canon, sobrecanon and mining royalties by the Jorge Basadre Grohmann National University.

\section{References}

1. Segura-Beltran, F. y Sanchis-Ibor, C. (2018). Estrechamiento de cauces y cambio en cursos fluviales mediterráneos como consecuencia del cambio global en las últimas seis décadas: indicadores geomorfológicos. En: García, C., Gómez-Pujol L., Morán-Tejeda, E. y Batalla, R.J. (eds), Geomorfología del Antropoceno. Efectos del Cambio Global sobre los procesos geomorfológicos: 395-398. Universitat de les Illes Balears, Sociedad Española de Geomorfología, Palma.

2. Nieto, A. (2020), La Mina del Futuro: Las 5S para la Innovación en la Industria Minera, Revista Minería, Perú, May, Vol. 512, pp. 14-23. online: $\mathrm{http} / / /$ mineriaonline.com.pe/mineria/512/16/

3. Hughe, L. - De Jong, M Thorne, Z. (2020). (De)coupling and (De)carbonizing in the economies and energy systems of the G20, Environment Development and Sustainability. DOI: $10.1007 / \mathrm{s} 10668-020-00834-7$

4. Pinillos, J., (2015). Tecnologías ecológicamente racionales para el manejo de las aguas en los depósitos de relaves mineros. Lima, UNFV, p. 30.

5. Palacios M, Alonso MM, Vargas C, Puertas F (2019) Influence of the alkaline solution and temperature on the rheology and reactivity of alkali-activated fly ash pastes. Cem Concr Compos 95:277-284.DOI: 10.1016/J. CEMCONCOMP.2018.08.010

6. Torrejón, J. A. V. (2015). Mecanismo de Producción más limpia: El Reúso de aguas residuales en la actividad minera. VOX JURIS, 30(2), pp. 263-278.

7. Wilson, D., Balkau, F. y Thurgood, M. (2005) "Solidificación y Estabilización". Manual de Formación en gestión de residuos peligrosos para países en vías de desarrollo.

Disponible:www.uneptie.org/pc/hazardouswaste/m enu.htm.

8. La Rotta, Á.,Torres, M. (2017). Mining and its health and environmental impacts. The case of Potosí in Bogotá https://doi.org/10.1590/01031104201711207

9. Instituto Peruano de Economía, (2017)." El valor agregado de la minería en el Perú", Primera edición. Hecho el Depósito Legal En La Biblioteca Nacional Del Perú N²017-06546, ISBN: 978612-47458-0-5.

10. Giannopoulou, I. y Panias, D. (2006)." Development of geopolymeric materials from industrial solid wastes". "Conference: 2nd International Conference on "Advances in Mineral Resources Management and Environmental Geotechnology”, AMIREG 2006Volume: pp. 69 73.

11. Waijarean N., Asavapisit, S., Sombatsompop, K., (2014). "Strength and microstructure of water treatment residue-based geopolymers containing heavy metals" Artículo publicado en Construction 
and Building Materials 50:486-491. DOI: 10.1016 /j. conbuildmat.2013.08.047.

12. Barrie, E., Cappuyns, V., Vassilieva, E., Adriaens, R., Hollanders, S., Garcés, D., Paredes, C., Pontikes, Y., Elsen, J., Machiels, L. (2015). "Potential of inorganic polymers (geopolymers) made of halloysite and volcanic glass for the immobilisation of tailings from gold extraction in Ecuador", Applied Clay Science 109-110:95-106. DOI: $10.1016 /$ j.clay.2015.02.025

13. Barbosa, V., MacKenzie, K., Thaumaturgo, C. (2000). "Synthesis and Characterization of Materials Based on Inorganic Polymers of Alumina and Silica: Sodium Polysialate Polymers." International Journal of Inorganic Materials 2(4): 309-317.

DOI: 10.1016 / S1466-6049 (00) 00041-6

14. Davidovits, J. (2011). Geopolymer Chemistry \& Applications. 3rd Edition. Institut Géopolymère. Saint-Quentin, France. Publisher: Institut Géopolymère, Geopolymer Institute, SaintQuentin, FranceEditor: Joseph Davidovits ISBN: 9782954453118 (5th ed.).

15. Davidovits, J. (1999) Chemistry of geopolymeric systems, terminology. In: Proceedings of 99 International Conference. France. 9-40. Davidovits, R. Davidovits \& C. James, France.

16. Kastiukas, G.; Zhou, X.; Castro-gomes, J. (2017) "Preparation conditions for the synthesis of alkaliactivated binders using tungsten mining waste". J. Mater. Civ. Eng. 2017, 29, 1-9.DOI: 10.1061/(ASCE)MT.1943-5533.0002029

17. Mackenzie, K., Waijarean, N., Asavapisit, S., Guy, N., Jamesonv, L. (2017). "Synthesis and properties of geopolymers based on water treatment residue and their immobilization of some heavy metals", Journal of Materials Science 52(12). DOI: 10.1007/s10853-017-0970-4

18. Waijarean Naprarath, Suwimol Asavapisit, Kwannate Sombatsompop. (2014). "Strength and microstructure of water treatment residue-based geopolymers containing heavy metals" Artículo publicado en Construction and Building Materials 50:486-491. DOI:

10.1016/j.conbuildmat.2013.08.047

19. Komnitsas, K., Zaharaki, D. (2007).

Geopolymerization: A review and prospects for the minerals industry. Minerals Engineering, pp.1261-1277. DOI:

10.1016/j.mineng.2007.07.011

20. Montes Valencia, Nancy. (2014). "Cementos Alcalinos: Materiales de Construcción Ecológicos" Revista CINTEX, Vol. 19, pp.109-125.

21. Baquero J., Fernández R., Verdejo J., lorca D. (2008). Tratamiento de Aguas Ácidas. Prevención y Reducción de la Contaminación, revista de la Sociedad Española de Mineralogía, ISSN 18857264, No 10, 2008, págs. 44-47.
22. Davidovits, J. (2017) "Geopolymers: Ceramic-like inorganic polymers," J. Ceram. Sci. Technol., vol. 8, no. 3, pp. 335-350, 2017. DOI: 10.4416/JCST2017-00038

23. Phair J., Deventer, V. (2001)." Effect of silicate activator $\mathrm{pH}$ on the leaching and material characteristics of waste-based inorganic polymers". DOI: 10.1016/S0892-6875(01)00002-4

24. Palomo, A., Blanco, M. (1999). Granizo M.L, Puertas F., Vázquez T. and Grutzeck M.W.; "Chemical stability of cementitious materials base on metakaolin". Cem. Concr. Res. Vol. 29. DOI: 10.1016/S0008-8846(99)00074-5

25. Hardjito, D., Wallah S., Sumajouw, D., Rangan, B. (2004). "Properties of Geopolymer Concrete with Fly Ash as Source Material: Effect of Mixture Composition". Paper999 to the Seventh CANMET/ACI International Conference on Recent Advances in Concrete Technology. Las Vegas, USA.

26. Samarakoon, M.; Ranjith, P.; Rathnaweera, T.; Perera, M. (2019). "Recent advances in alkaline cement binders: A review". J. Clean. Prod. 2019, 227, 70-87.4. DOI: 10.1016/j.jclepro.2019.04.103

27. Cristelo Nuno, Coelho João, Oliveira Mafalda, Consoli Nilo Cesar, Palomo Ángel FernándezJiménez Ana. (2020). Recycling and Application of Mine Tailings in Alkali-Activated Cements and Mortars-Strength Development and Environmental Assessment. Applied Sciences 10(6):2084. DOI: 10.3390/app10062084

28. Lee, S.; van Riessen, A.; Chon, C.M.; Kang, N.H.; Jou, H.T.; Kim, Y.J. (2016). Impact of activator type on the immobilisation of lead in fly ash-based geopolymer. J. Hazard. Mater. 305,59-66.DOI: 10.1016/j.jhazmat.2015.11.023.

29. I Capasso, S. Lirer, A. Flora, C. Ferone, R. Cioffi, D. Caputo, B. Liguori. (2019) Reuse of mining waste as aggregates in fly ash-based geopolymers. Journal of Cleaner Production 220. DOI: 10.1016/j.jclepro.2019.02.164.

30. Boca Santa R, Viana da Silva A, Padoin N, SoaresC, Gracher Riella H (2019) Novel porous geopolymeric formulation as green material applied to the recovery of contaminated effluent aiming environmental protection. Journal of Cleaner Production. DOI: 10.1016/j.jclepro.2019.05.213.

31. Kuenzela C, Ranjbarb N. (2019) Dissolution mechanism of fly ash to quantify the reactive aluminosilicates in Geopolymerisation. Journal Resources Conservation and Recycling. 10.1016/j.resconrec.2019.104421

32. Morales-Aranibar C, Linares N, Morales-Aranibar L (2021). Immobilization of copper sulfide flotation tailings through the use of geopolymers, Tacna - Perú. IOP Conference Series: Materials Science and Engineering, Volume 1065, 1st International Conference on Frontiers in 
Engineering Science and Technology (ICFEST 2020) December 18th-19th 2020, Mangalore, India, doi:10.1088/1757-899X/1065/1/012009.

33. Yu Q, Li S, Li H, Chai X, Bi X, Liu J, Ohnuki T. (2019) Synthesis and characterization of Mn-slag based geopolymer for immobilization of Co.

Journal of Cleaner Production.

DOI:10.1016/j.jclepro.2019.06.149. 